\title{
TRANSLATING THAT: AN IDEATIONAL CORRESPONDENCE ANALYSIS OF MACHINE TRANSLATION
}

\author{
Ardik Ardianto ${ }^{1 *}$ \\ ${ }^{1}$ Universitas Gadjah Mada, Indonesia \\ *e-mail: ardikardianto@gmail.com
}

\begin{abstract}
Abstrak
Penelitian ini bertujuan untuk membandingkan hasil terjemahan dua mesin terjemahan, yakni Google Translate dan Bing Translator, dalam menerjemahkan leksem that pada artikel berita. Pendekatan yang digunakan dalam menelaah kesejajaran hasil terjemahan dari leksem that pada penelitian ini adalah linguistik sistemik fungsional, khususnya pada struktur eksperiensial dan logis. Jenis analisis yang digunakan adalah komparatif deskriptif. Data yang digunakan meliputi 40 satuan kebahasaan dari leksem that yang diambil dari enam artikel Berita Dunia BBC. Hasil temuan menunjukkan bahwa dua mesin terjemahan mampu mengenali tiga fungsi leksem that, yakni fungsi inti (Head), fungsi post-modifier, dan fungsi konjungsi. Fungsi terbanyak yang ditemukan adalah fungsi post-modifier (19 kali atau 47,5\%), yang diikuti dengan fungsi konjungsi (17 kali atau $42,5 \%$ pada mesin pertama dan 18 kali atau $45 \%$ pada mesin kedua). Fungsi inti menjadi fungsi terakhir setelah kedua fungsi lainnya (empat kali atau $10 \%$ pada mesin pertama dan tiga kali atau 7,5\% pada mesin kedua). Lebih lanjut, dikarenakan adanya variasi elipsis dari leksem that sebagai pronomina relatif dan post-determiner pada mesin terjemahan pertama, penelitian ini menyimpulkan bahwa hasil terjemahan mesin pertama lebih akurat, berterima, kreatif, dan kontekstual daripada hasil terjemahan mesin kedua.
\end{abstract}

Kata kunci: Linguistik Sistemik Fungsional; Struktur Eksperiensial; Struktur Logis

\begin{abstract}
This paper aims to contrast the translation of two machine translation systems, Google Translate and Bing Translator, in translating the lexeme in news articles. The approach used in scrutinizing the lexeme's translation correspondence in this study is systemic functional linguistics, especially in both experiential and logical structures. This study was carried out through descriptive comparative analysis. This study's data were 40 constituents that were taken from six BBC World news articles randomly selected. A thorough analysis demonstrates that the two machine translation systems can recognize the three functions of that, i.e., Head, post-modifier, and conjunction. The highest emerging function is post-modifier by 19 times $(47.5 \%)$, followed by the conjunction function by 17 times $(42.5 \%)$ on the first machine translation system and 18 times (45\%) on the second one. The lowest emerging function is Head by four times $(10 \%)$ on the first machine translation system and three times $(7.5 \%)$ on the second one. Furthermore, due to the elliptical variation of that as a relative pronoun and the translation variation of that as a post-determiner, it concludes that the translation outputs of Google Translate are more accurate, semantically acceptable, creative, and contextual than those of Bing Translator.
\end{abstract}

Keywords: Experiential Structure; Logical Structure; Systemic Functional Linguistics

This is an open access article under the CC BY-SA license.

Copyright $@ 2021$ by Author. Published by Universitas Pendidikan Ganesha.

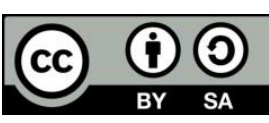




\section{INTRODUCTION}

Translation, nowadays, does not merely involve the manual translation process by a human translator; further, following the global information technology trends, translation has begun to enter a new era, i.e., the digital translation era. In the last several decades, digital translation started getting notable attention in translation studies. In general, there are numerous experts acceding that the digital translation consists of two central classifications, computer-assisted translation and machine translation (Hartley, 2009; Williams \& Chesterman, 2002). According to Munday (2016), the distinctive features of these two classifications reside in the process and the intended use. The computer-assisted translation rather highlights the assistance process in facilitating, accelerating, and easing the series of translation processes carried out by a human translator, ranging from the pre-translation to post-translation process. Whilst, the machine translation is increasingly used in the initial informationdistributing process, which in this case refers to the preliminary draft composition (often undertaken by the European Commission). It aims at triggering varied inputs or feedbacks for further reviews, editing, and proofreading by professional translators.

Machine translation is an automated and independence computational system to translate a text (Ahangar et al., 2012). This automated computational system was then developed so as to further facilitate the process of translating one language to another in the absence of any human assistance. During its development over the past fifty years, automatic machine translation has been enhanced and refined through numerous paradigms, including dictionary-based machine translation, example-based machine translation, and rule-based machine translation (Pilevar \& Faili, 2010). Inevitably, each type has its own advantages and drawbacks.
Several studies have evinced that despite its incredibly rapid progress, rulebased machine translation seemingly still encounters a number of difficulties in translating various languages. Putri and Ardi (2015), for instance, demonstrated that the rule/statistic-based machine translation, i.e. Google Translate (GT), faced varied difficulties in translating folklore texts from Indonesian language to English, such as 1) inequivalent/incorrect and omitted diction, 2) errors in the word, phrase, even sentence structure, and 3) errors in translating unknown words or realia. In accord with these findings, Ismail and Hartono (2016) in their study showed that GT also encountered many difficulties in translating news articles from Indonesian language to English. The major difficulties found in the study were mainly related to grammatical and terminological errors-apart from other errors, e.g., the ambiguity creation, and punctuation and capitalization errors. It also concluded that the difficulties occurred due to varied factors, including the lack of machine ability to recognize the context of the text provided (bearing in mind that GT is mainly based on statistics/rules), and the machine incapability of identifying errors existed in the source texts and consequently created errors in the target texts.

However, despite those difficulties and errors, recently due to the current Neural Machine Translation (NMT) system, both GT and Bing Translator (BT) generated outstanding results (> 90\% accuracy) pertaining to the orthography and grammar and good ones on the lexical and grammatical collocations $(79.8 \%$ for GT and $74.5 \%$ for $\mathrm{BT}$ ) in translating journalistic texts (Almahasees, 2018). Similar to this findings, Achmad (2016) also pointed out that the translation quality of GT is better than that of $\mathrm{BT}$ as regards scientific texts. 
Although several studies mentioned have investigated errors occurred in machine translation outputs, to some extent there has not been yet any studies contrasting the outputs of two machine translation systems, particularly focusing on the lexeme that. I assume that due to the use of a distinct corpora database, one machine translation system will produce different outputs contrasted with another one. Therefore, this paper strives to scrutinize how such contrast is actualized in the outputs of these two machine translation systems. The rationale behind the selection of GT and BT in this study was due to their well-known good quality (Achmad, 2016; Almahasees, 2018) and their popularity throughout the world (Precup-Stiegelbauer, 2013). The contrastive analysis incorporates two shift aspects, i.e. the structural shift and the syntactical function shift, especially on the ideational structure ${ }^{1}$ (cf. Dwijatmoko, 2019, who used three metafunctions in his analysis).

In analyzing both syntactical structure and function, Halliday and Matthiessen (2014) proposed two main structures, namely experiential structure and logical structure of each constituent. The experiential structure refers to the element of THING in each constituent class; meanwhile, the logical structure refers to the element of how the logic of the constituent classes works in the larger construction. The experiential structure in a noun phrase, for instance, is classified into four categories, i.e., deictic, numerative, epithet, and classifier. Whereas, the logical structure is merely classified into two categories, namely pre-modifier and postmodifier. For further details regarding these two structures, it can be seen in the Table 1.

Table 1. Experiential and Logical Structures of Noun Phrase (1)

Modified from Halliday (Ibid.)

(1) Those two-splendid old electric trains with pantographs

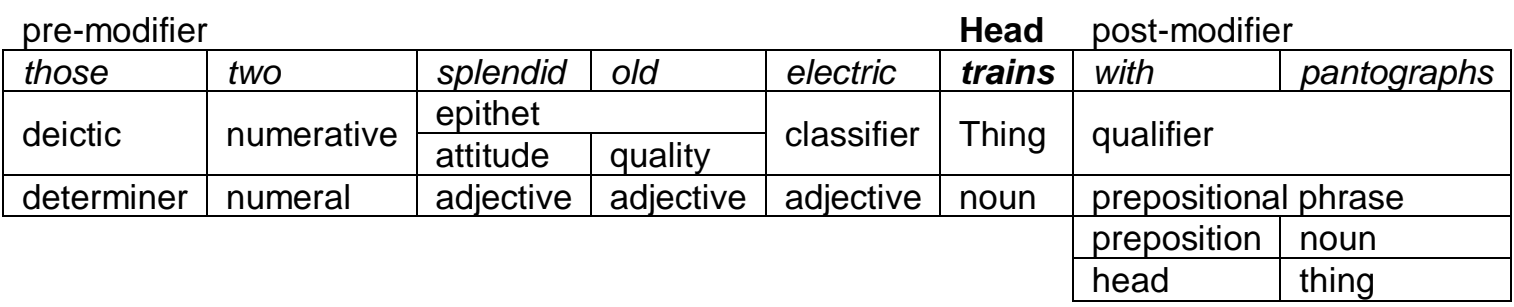

As illustrated in Table 1, these experiential and logical structures merely represent the syntactical slots wherein the realization of each slot can be filled by various constituents. Therefore, it can be said that a constituent, whether it is in the form of word, compound word, or even phrase, can fill each categorical slot freely or flexibly. In regard to this, it is highly possible for the lexeme that to play a role or fill distinct categories depending on the function preferred. Perceived from its logical structure category, the lexeme that can occupy three categories, i.e., as a premodifier, as a Head, and as a post-modifier, as well as one function as a conjunction.

1. That as a Pre-modifier

The lexeme that as a premodifier is realized in the form of demonstrative determiner, functioning as a deictic. Demonstrative in this context indicates two aspects, namely

Jurnal IImu Sosial dan Humaniora | 13 
1) proximity or distance, that is far from the collocutor; and 2) quantity, that is singular. Furthermore, the determiner in this example also functions as a deictic, in that it attributes the definiteness on the noun Head (Thing). The detailed elaboration on this can be seen in Table 2.

Table 2. That as a Pre-modifier

(2) That man under the tree is my brother

\begin{tabular}{|c|c|c|c|c|}
\hline pre-modifier & Head & \multicolumn{3}{|c|}{ post-modifier } \\
\hline that & man & under & the & tree \\
\hline deictic & Thing & \multicolumn{3}{|c|}{ qualifier } \\
\hline $\begin{array}{c}\text { demonstrative } \\
\text { determiner }\end{array}$ & \multirow{2}{*}{ noun } & \multicolumn{2}{|c|}{ prepositional phrase } \\
\hline \multirow{2}{*}{} & preposition & \multicolumn{2}{|c|}{ noun phrase } \\
\cline { 2 - 4 } & Head & \multicolumn{2}{|c|}{ Thing } \\
\cline { 3 - 4 } & \multicolumn{2}{c}{ determiner } & noun \\
\cline { 3 - 4 }
\end{tabular}

2. That as a Head

Apart from being a pre-modifier, the lexeme that can function as a Head in either subject or object of a sentence. Due to its function as a
Head, this constituent thus can independently exist without other constituents to modify it. Table 3 below illustrates that as a Head in either subject or object of a sentence.

Table 3. That as a Head

\begin{tabular}{|l|l|}
\hline Subject & That is the problem we should face. \\
\hline Object & I do not eat that \\
\hline
\end{tabular}

3. That as a Post-modifier

The third function of the lexeme that is as a post-modifier of a noun Head in the form of relative pronoun (as a qualifier) used to initiate a relative clause. In its realization, the lexeme that is not necessarily required (rather, optional), and ergo can be omitted if necessary. The following examples, sentence (3) and (3a), demonstrate that as a post-modifier.

Table 4. That as a post-modifier

The cat that ate your fish came to me last night (3a) The cat eating your fish came to me last night

\begin{tabular}{|c|c|c|c|c|c|}
\hline pre-modifier & Head & \multicolumn{4}{|c|}{ post-modifier } \\
\hline the & cat & that & ate & your & fish \\
\hline deictic & Thing & & \multicolumn{2}{|c|}{ qualifier } \\
\hline determiner & noun & relative pronoun & verb & noun phrase \\
\cline { 3 - 5 } & & $\begin{array}{l}\text { possessive } \\
\text { determiner }\end{array}$ & noun \\
\cline { 3 - 5 }
\end{tabular}


4. That as a Conjunction

Last, the lexeme that can also function as a conjunction to introduce a subordinate clause, whether as a noun clause (subject-object) or as a complement clause.

Table 5. That as a post-modifier

\begin{tabular}{|c|l|}
\hline \multicolumn{2}{|c|}{ Noun Clause } \\
\hline Subject & That he always loves you is the fact you cannot deny \\
\hline Object & I know that he always loves you \\
\hline \multicolumn{2}{|c|}{ Complement Clause } \\
\hline \multirow{2}{*}{ Subject } & The fact is that he always loves you \\
\cline { 2 - 2 } & I am sure that he always loves you \\
\hline
\end{tabular}

This study aimed at scrutinizing the ideational structures of the lexeme that in the two machine translation systems. The analysis was carried out by contrasting, therefore finding out the similarities and differences, the experiential structure and logical structure of those lexemes. It was specifically focused on two aspects, i.e., function and category of the lexeme that. This study, moreover, was expected to be of beneficiary for describing how the lexeme that was translated into the two machine translation systems and to what extent the translation outputs were corresponded to the originals in terms of both function and category in the experiential and logical structures.

\section{METHODS}

This study is a contrastive analysis focusing on two major axes, i.e., similarities and differences of the translation of two machine translation systems in translating the lexeme that. The machine translation systems used were Google Translate and
Bing Translator. These two systems were selected on the grounds that both are the most popular machine translation systems that are frequently used worldwide (PrecupStiegelbauer, 2013). The data were retrieved from the global news channel, that is $B B C$ News, consisting of six news articles randomly selected. The data of this study comprised forty constituents that in English (Source Text) and the translation in Indonesian language (Target Text). The data analysis was carried out in two stages: 1) the percentage calculation of each function and category of the lexeme that in both machine translation systems; 2) the elaboration of contrastive analysis (similarities and differences) of the translation.

\section{FINDINGS AND DISCUSSION}

Based on the translation of the two machine translation systems, i.e., Google Translate (GT) and Bing Translator (BT), each function and category of the lexeme that is thoroughly elaborated in the Table 6.

Table 6. The overview of function and category in Google Translate

\begin{tabular}{|c|c|c|c|c|}
\hline \multirow{2}{*}{ System } & \multirow{2}{*}{ Function } & \multirow{2}{*}{ Category } & \multicolumn{2}{|c|}{ Percentage } \\
\hline & & & Partial & Total \\
\hline 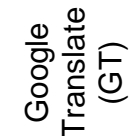 & Head & $\begin{array}{l}\text { pronoun (begitulah) } \\
\text { pronoun (itulah) } \\
\text { pronoun (itu) }\end{array}$ & $\begin{array}{c}1(2.5 \%) \\
1(2.5 \%) \\
2(5 \%)\end{array}$ & $4(10 \%)$ \\
\hline
\end{tabular}




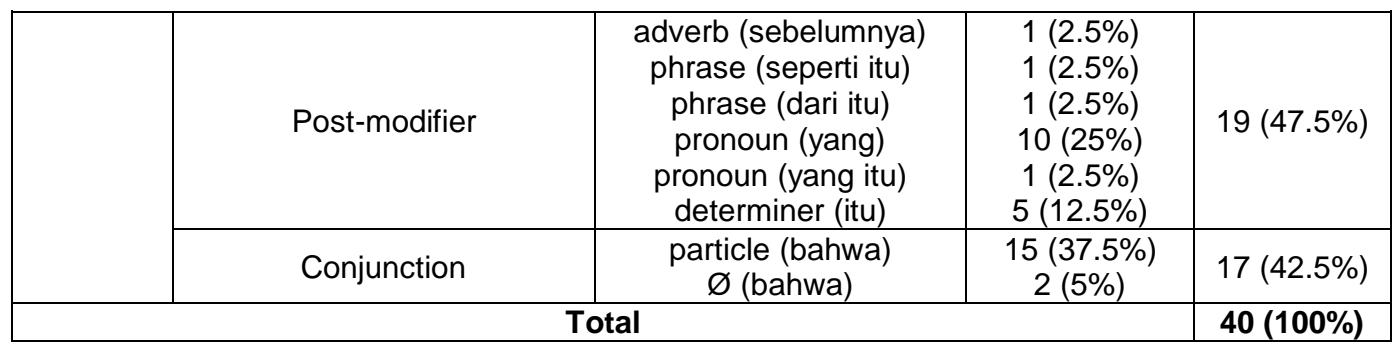

Table 7. The overview of function and category in Bing Translator

\begin{tabular}{|c|c|c|c|c|}
\hline \multirow{2}{*}{ System } & \multirow{2}{*}{ Function } & \multirow{2}{*}{ Category } & \multicolumn{2}{|c|}{ Percentage } \\
\hline & & & Partial & Total \\
\hline \multirow{3}{*}{ 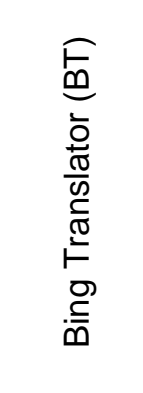 } & Head & $\begin{array}{l}\text { pronoun (itulah) } \\
\text { pronoun (itu) }\end{array}$ & $\begin{array}{c}2(5 \%) \\
1(2.5 \%)\end{array}$ & $3(7.5 \%)$ \\
\hline & Post-modifier & $\begin{array}{l}\text { adverb (sebelum itu) } \\
\text { phrase (seperti itu) } \\
\text { phrase (dari itu) } \\
\text { pronoun (yang) } \\
\text { pronoun (yang satu) } \\
\text { determiner (itu) }\end{array}$ & $\begin{array}{c}1(2.5 \%) \\
1(2.5 \%) \\
1(2.5 \%) \\
10(25 \%) \\
1(2.5 \%) \\
5(12.5 \%) \\
\end{array}$ & $\begin{array}{c}19 \\
(47.5 \%)\end{array}$ \\
\hline & Conjunction & particle (bahwa) & & $18(45 \%)$ \\
\hline \multicolumn{4}{|c|}{ Total } & $40(100 \%)$ \\
\hline
\end{tabular}

From the table 6 and 7 above, it can be seen that the most frequently occurring function of the lexeme that was as post-modifier (19 times or $47.5 \%$ in each machine translation system). On the first machine, such function of post-modifier was distributed in the form of the adverb sebelumnya (previously) once (2.5\%), the phrase seperti itu (such that) once $(2.5 \%)$, the phrase dari itu (of which) once (2.5\%), the relative pronoun yang (that) by ten times $(25 \%)$, the demonstrative relative pronoun yang itu (that one) once (2.5\%), and the deictic determiner itu (that) by five times (12.5\%). Meanwhile on the second machine, it was distributed in the form of the adverb sebelum itu (prior to that) once $(2.5 \%)$, the phrase seperti itu (such that) once $(2.5 \%)$, the phrase dari itu (of which) once $(2.5 \%)$, the relative pronoun yang (that) by ten times $(25 \%)$, the relative pronoun yang satu (that one) once (2.5\%), and the deictic determiner itu (that) by five times $(12.5 \%)$. The difference of these two machines relied on the adverbs sebelumnya - sebelum itu (previously and prior to that) and relative pronouns yang itu - yang satu (both mean that one). Furthermore, the second most occurring function was as conjunction, realized in the form of the Indonesian particle bahwa (that). On the first machine, this function of conjunction occurred 17 times (42.5\%) distributed into two, i.e., the Indonesian particle bahwa (that) by 15 times (37.5\%) and $\varnothing$ twice $(5 \%)$; whereas, on the second machine, it occurred 18 times (45\%). The function of Head occurred in the third place, in the form of the pronoun begitulah (that so) and itulah (that) by four times (10\%) in the first machine and in the form of the pronoun itulah (that) by three times $(7.5 \%)$ in the second one. 


\section{Similarities of the Two Machine Translation Systems}

\section{That as a Head}

The two machines generated the similar translation as to the function of that as a Head. Both put the pronoun that as the Head of the subject of the sentence.

That's barely enough money to pay the rent. (Article 3)

Translation:

GT : Itu hampir tidak cukup uang untuk membayar sewa.

BT : Itu hampir tidak cukup uang untuk membayar sewa.

\section{That as a Post-modifier}

The translation similarity between these two machines can be seen in several sentences containing the determiner as follows:

"You have taken that grief and turned it into a wonderful opportunity to try and help people who have suffered as you have suffered," George Brandis said. (Article 2)

Translation:

GT : "Anda telah menerima kesedihan kesempatan yang luar biasa untuk mencoba dan membantu orang-orang yang telah menderita seperti yang Anda derita," kata George Brandis.

"Anda telah mengambil kesedihan itu dan mengubahnya menjadi kesempatan yang indah

BT : untuk mencoba dan membantu orang yang telah menderita seperti yang Anda telah menderita," kata George Brandis.

From the translation above, it can be recognized that the structure of noun phrase that grief did not undergo such categorical shift at all. Nevertheless, due to the distinct syntactical construction between the English language and the Indonesian language, the logical structure of premodifier was transformed into postmodifier. ${ }^{2}$ This such categorical shift-in Vinay and Darbelnet's term "servitude or obligatory transposition" (Munday, 2016, p. 93; Vinay \& Darbelnet, 1995, pp. 27-30)inevitably occurs in two languages with a different syntactical construction.

Table 8. Experiential - logical structures (English - Indonesian language)

\begin{tabular}{|c|c|}
\multicolumn{1}{c|}{ pre-modifier } & \multicolumn{1}{c}{ Head } \\
\hline that & grief \\
\hline deictic & Thing \\
\hline determiner & noun \\
\hline
\end{tabular}

Demonstrative determiner

Pre-modifier

Noun Head

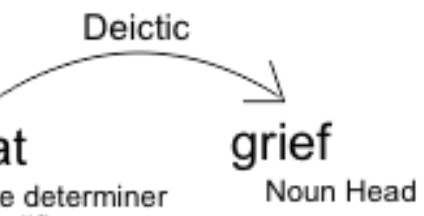

\begin{tabular}{|c|c|}
\hline \multicolumn{1}{c}{ Head } & post-modifier \\
\hline kesedihan & deictic \\
\hline Thing & determiner \\
\hline nomina & Deictic \\
\hline \\
$\begin{array}{c}\text { kesedihan } \\
\text { Noun Head }\end{array}$ \\
Demonstrative determiner \\
Post-modifier
\end{tabular}

Jurnal IImu Sosial dan Humaniora | 17 


\section{That as a Post-modifier and a Conjunction}

In this section, it is noteworthy to bear in mind that despite embodying three different lexemes that in one complex sentence, both machines were able to identify their distinct functions-two lexemes functioned as post-modifier in the form of relative pronoun yang (that), and the rest lexeme functioned as the conjunction in the form of the Indonesian particle bahwa (that) followed by the object complement clause.
"This gives the first demonstration that in the wild there is a correlation between populations that get disease and populations that remain disease-free, and the mix of bacteria on the skin," said Dr Lewis Campbell from the University of Exeter. (Article 1)

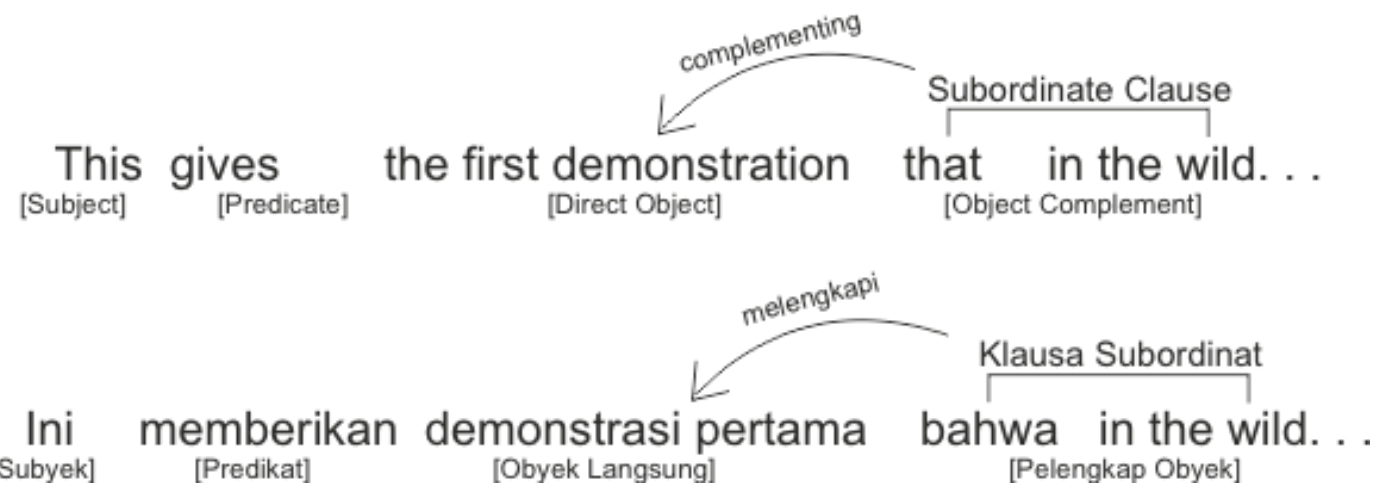

Illustration 1. The conjunction function in English and Indonesian language

As for the experiential and logical structures of the lexeme that as a post-modifier, it can be seen in the following Table 9 and 10.

Table 9. Experiential - logical structures of the lexeme that as a post-modifier (English)

Head post-modifier

\begin{abstract}
Translation:
"Ini memberikan demonstrasi pertama bahwa di alam liar ada korelasi antara populasi yang mendapatkan penyakit dan

GT : populasi yang tetap bebas penyakit, dan campuran bakteri pada kulit," kata $\mathrm{Dr}$ Lewis Campbell dari University of Exeter.

"Ini memberikan demonstrasi pertama bahwa di alam liar ada korelasi antara populasi yang mendapatkan penyakit dan

BT : populasi yang tetap bebas penyakit, dan campuran bakteri pada kulit," kata $\mathrm{Dr}$ Lewis Campbell dari University of Exeter.
\end{abstract}

\begin{tabular}{|c|c|c|c|}
\hline population & that & get & disease \\
\hline Thing & \multicolumn{3}{|c|}{ qualifier } \\
\hline noun & $\begin{array}{c}\text { relative } \\
\text { pronoun }\end{array}$ & verb & noun \\
\hline
\end{tabular}

Table 10. Experiential - logical structures of the lexeme that as a post-modifier (Indonesian language) 


Head
\begin{tabular}{|c|c|c|c|}
\hline $\begin{array}{c}\text { populas } \\
\boldsymbol{i}\end{array}$ & yang & $\begin{array}{c}\text { mendapatka } \\
n\end{array}$ & $\begin{array}{c}\text { penyaki } \\
t\end{array}$ \\
\hline Thing & \multicolumn{3}{|c|}{ qualifier } \\
\hline noun & $\begin{array}{c}\text { relative } \\
\text { pronou } \\
\mathrm{n}\end{array}$ & verb & noun \\
\hline
\end{tabular}

\section{Differences of the Two Machine} Translation Systems

Albeit the translation of these two machines was mostly equal in term of sentence construction, there were still differences emerging between Google and Bing Translator. The following section will elaborate such differences.

\section{Elliptical Variation of the Relative Pronoun That}

It's not the first time that militias and libertarians in the state have made headlines. (Article 4)

Translation:

Ini bukan pertama kalinya $\varnothing$ (bahwa) milisi dan libertarian di

GT : negara bagian ini menjadi berita utama.

Ini bukan pertama kalinya bahwa milisi dan libertarian di negara telah membuat berita utama.

Based on the translation above, it can be identified that in the first machine, the lexeme that was omitted whereas in the second one was translated into the Indonesian particle bahwa. The subordinate function, which to some degree refers to the relative pronoun that, was basically optional and thus could either be presented or omitted (Thomas, 1993). Due to its optionality, the translation of the first machine can be considered acceptable semantically and syntactically. In fact, based on the similarity of other findings acquired, it can be proven that the first machine, Google Translate, was indeed more creative and could generate more variants in translating the relative pronoun that as a conjunction than the second one, Bing Translator. There was none of the translation generated by Bing Translator pertaining to the omission of the relative pronoun. It affirmed several studies (Achmad, 2016; Almahasees, 2018) pointing out that Google Translate is more creative and readable than Bing Translator.

\section{Translation Errors}

It was found that there were translation errors in the second machine, Bing Translator, while translating the lexeme that as a subordinator of the following subordinate clause. The following examples illustrate how such errors occurred in the translation.

It's part of a bigger project

that Ashee hopes will eventually incorporate a medical centre and additional housing.

(Article 3)

Translation:

Itu bagian dari proyek yang lebih besar yang diharapkan Ashee

GT : pada akhirnya akan menggabungkan pusat medis dan perumahan tambahan.

Ini adalah bagian dari proyek yang lebih besar bahwa Ashee

BT : berharap pada akhirnya akan menggabungkan pusat medis dan perumahan tambahan.

The second machine translated the subordinator that into the Indonesian particle bahwa instead of the relative pronoun yang. Such translation cannot be considered acceptable due to the distinct function of yang (relative pronoun) and bahwa (particle) in the Indonesian language system. Specifically, there is only one single Jurnal IImu Sosial dan Humaniora | 19 
acceptable translation to translate the lexeme that as a relative pronoun in a subordinate clause, that is the pronoun yang. Besides, in terms of the sentence structure, the translation of the second machine seems unnatural and highly literal compared to one of the first machine-Google Translate could even transform the diathesis of the relative clause structure from the active construction in the ST into the passive construction in the TT.

\section{Translation Variation of That as a} Post-modifier

Apart from its ability of generating the elliptical variation of the relative pronoun that, Google Translate could also achieve the variant equivalence of the lexeme that as a post-modifier through the use of adverbs (temporal adverbial). This differed from the translation of the second machine, Bing Translator, that seemingly tended to translate every constituent literally by word-for-word.

Before that he used the name Saima, and wore women's clothes, but had to give up his third-gender identity to gain his family's acceptance.

\section{(Artikel 3)}

Translation:

Sebelumnya dia menggunakan nama Saima, dan mengenakan pakaian wanita, tetapi harus

GT : melepaskan identitas gender ketiga untuk mendapatkan penerimaan keluarganya.

Sebelum itu ia menggunakan nama Saima, dan mengenakan

BT : pakaian wanita, tetapi harus menyerah identitas gender ketiga untuk mendapatkan penerimaan keluarganya.
Although these two translations, sebelumnya and sebelum itu, are acceptable semantically and syntactically in the Indonesian language, the use of translation variant in the first machine gives added values for Google Translate over Bing Translator. Besides, by using the adverb sebelumnya, the translation generated by Google Translate seems more contextual and natural than one of Bing Translator, which tended to be formal. Through its ability of translating the phrase before that into the single adverb sebelumnya, it can be justified that the algorithm used by Google Translate does not focus solely on word-for-word equivalence, but also on its pragmatic use.

\section{CONCLUSION AND RECOMMENDATION}

Translating the lexeme that becomes one of many challenging issues for machine translation since it possesses various distinct functions and categories. Based on the findings acquired, it can be said that the two machine translation systems, Google Translate and Bing Translator, could translate the lexeme that very well-regardless several translation irregularities in the second machine. Furthermore, both machines could properly identify the three functions of the lexeme that, i.e., as a Head, as a post-modifier, and as a conjunction. The function of postmodifier was the most frequently occurring function by 19 times (47.5\%), followed by the function of conjunction by 17 times $(42.5 \%)$ in the first machine and by 18 times $(45 \%)$ in the second one. The function of Head ranked third with the occurrence frequency of four times (10\%) in the first machine and of three times $(7.5 \%)$ in the second one. To sum up, due to a number of considerations, such as the elliptical variation of the relative pronoun that and the translation variants of the lexeme that as a post-modifier, the translation outputs of Google Translate were considered more 
accurate, semantically acceptable, creative, and contextual than those of Bing Translator.

\section{ENDNOTE}

1. The ideational structure, in this study, is derived from the systemic functional linguistics by Halliday (2014) used to identify a phrase construction in a clause.

2. Despite the transformation of the logical structure of pre-modifier into postmodifier as the result of adapting the Indonesian syntactical system, the experiential function of its constituents, however, remained the same.

\section{REFERENCES}

Achmad, A. (2016). Kualitas terjemahan teks ilmiah hasil penerjemahan mesin Google Translate dan Bing Translator. Indonesian Journal of Applied Linguistics Review, 1(1), 1-20.

Ahangar, A. A., Jahangiri, N., \& Mohammadpour, F. (2012). A Lexicalfunctional model for machine translation of English zero-place predicators into Persian. International Journal of English Linguistics, 2(3), 29. https://doi.org/10.5539/ijel.v2n3p2

Almahasees, Z. M. (2018). Assessment of Google and Microsoft Bing translation of journalistic texts. International Journal of Languages, Literature and Linguistics, 4(3), 231-235.

Briggs, H. (2019, June 22). 'Friendly' bacteria could help save frogs from disease. BBC News. Retrieved from https://www.bbc.com/news/scienceenvironment-48707650.

Dwijatmoko, B. B. (2019). Life and death in Andersen's "Grandmother": A systemic functional grammar analysis. Jurnal Kata: Penelitian Tentang IImu Bahasa Dan Sastra, 3(1), 144-154.

Halliday, M. A. K., \& Matthiessen, C. M. I. M. (2014). Halliday's introduction to functional grammar. Routledge.

Hartley, A. (2009). Technology and translation. In J. Munday (Ed.), The routledge companion to translation studies (pp. 106-127). Routledge.

Inside Pakistan's first retirement home for third-gender people (2019, June 21), $B B C$ News. Retrieved from https://www.bbc.com/news/stories48707042.

Iran: New US sanctions target Supreme Leader Khamenei (2019, June 24). $B B C$ News. Retrieved from https://www.bbc.com/news/world-uscanada-48748544.

Ismail, A., \& Hartono, R. (2016). Errors made in Google Translate in the Indonesian to English translations of news item texts. Journal of English Language Teaching, 5(2), 1-6.

London bridge attack: Sara Zelenak's parents begin charity bike ride (2019, June 23), BBC News. Retrieved from https://www.bbc.com/news/ukengland-london-48736087.

Munday, J. (2016). Introducing translation studies: Theories and applications (5th ed.). Routledge.

Pilevar, M. T., \& Faili, H. (2010). PersianSMT: A first attempt to EnglishPersian statistical machine translation. JADT 2010: 10th International Conference on Statistical Analysis of Textual Data, 1101-1111.

Precup-Stiegelbauer, L.-R. (2013). Automatic Translations Versus Human Translations in Nowadays World. Procedia - Social and Behavioral Sciences, 70, 1768-1777. https://doi.org/https://doi.org/10.1016/j. sbspro.2013.01.252

Putri, G. G., \& Ardi, H. (2015). Types of errors found in Google Translation: A model of MT evaluation. Proceedings of the Third International Seminar on English Language and Teaching (ISELT-3), 183-188.

Thomas, L. (1993). Beginning syntax. Blackwell.

Tory leadership race: Boris Johnson 'ducking important questions' (2019, 
June 23), BBC News. Retrieved from https://www.bbc.com/news/uk-politics48736968.

Vinay, J.-P., \& Darbelnet, J. (1995). Comparative stylistics of French and English: A methodology for translation. John Benjamins.

Why a group of US state senators are being hunted by police (2019, June 23), $B B C$ News. Retrieved from https://www.bbc.com/news/world-uscanada-48737711.

Williams, J., \& Chesterman, A. (2002). The map: A beginner's guide to doing research in translation studies. St. Jerome Pub. 